\title{
Teaching Practicum in Pre-Service Teacher Education
}

\author{
Dwiyani Pratiwi \\ Pendidikan Bahasa Inggris, Pascasarjana, Fakultas Sastra, Universitas Negeri Malang \\ Email: dwiyani.1702219@students.um.ac.id
}

\begin{abstract}
This paper presents a review of the research literature on practicum. Since there have been changes in trends in Teaching Education since the 1960s that also influenced the shift of research topics on practicum, this paper first gives a short review of the research trends in general TE, changing from the teaching processproduct paradigm to the investigation of teachers' mental lives or cognition. Then the actual review will focus on the studies related to the teachers' beliefs, perspectives, perceptions, understanding, and reasoning, and follows under these topics: student teachers learning, cooperating teachers, and school-university cooperation in the practicum. At the end of this paper, some future studies on teaching practicum are suggested.
\end{abstract}

Keywords: Teaching Practicum; Teacher Education.

\section{INTRODUCTION}

Pre-service Teacher Education (PTE) programs require their student teachers to get a real teaching experience in a school or a college where they learn how to interact with actual learners. This session of PTE is called practicum or teaching practice (TP). A variety of terms is used to refer to practicum, including practice teaching, field experience, apprenticeship, practical experience, and internship.

Generally, practicum means the opportunity given to the trainee teachers or student teachers to develop and improve their professional practice in the context of a real classroom, usually under some form of guidance and supervision (Wallace, 1991). The practicum is considered one of the important elements in student-teacher education. In some PTE programs, it is a compulsory course taken by student teachers. However, some universities appear not to provide their student teachers to do the practicum at schools. Some university commentators have said that a poor practicum experience may be of little or no value. While universities often neglect the practicum, the university researchers think that it is a regrettable state of affairs rather than something to be accepted (Beck \& Kosnik, 2002).

Practicum becomes very essential in a student-teacher education for some reasons i.e. to (1) gain practical classroom teaching experience, (2) apply theory and teaching ideas from previous course work, (3) discover from observing experienced teachers,(4) enhance lesson-planning skill, (5) gain skills in selecting, adapting, and developing 
origin course materials, (6) expand awareness of how to set their own goals related to improving their teaching, (7) question, articulate, and reflect on their teaching and learning philosophies, and (8) see their teaching differently by learning how to make their own informed teaching decisions through systematic observation and exploration of their own and others' teaching (Gebhard, 2009).

The discussion of teaching practicum has gradually changed since the 1960s, following the shift of trend in Teaching Education (TE) in general. Therefore, before exploring the research and practice on the practicum, I would start with a short review of the research trends in general TE. Before the mid-1970s, policy and research in education drew strongly on the process-product paradigm which examines teaching in terms of learning outcomes it produced. Based on this paradigm, the research was aimed at understanding "how teachers' actions led - or did not lead to student learning" (Freeman, 2002:2). During this period, there was a belief that "learning to teach involved mastering the specific content one was to teach and separately mastering methodologies for conveying the content to learners" (Freeman, 2002: 4). In this period, then, the teacher was viewed as a 'doer' as an implementer of other people's ideas (2002: 5). It was questioned then that the teacher did not have prior knowledge, background, 'mental life' to support him to do the teaching. Borg states that "teachers are active, thinking decision-makers who play a central role in shaping classroom events and make instructional choices by drawing on complex, practically oriented, personalized, and contextsensitive networks of knowledge, thoughts, and beliefs (Ong'ondo \& Jwan, 2009: 516). Consequently, the years from 1980 to 1990 marked a full decade of change and reconceptualization from the processproduct paradigm to the investigation of teachers' knowledge, beliefs, perspectives, thinking, reasoning, etc. It has been used in different terms'the hidden side of teaching' (Freeman, 2002), 'teacher cognition' (Borg, 2003), or pedagogical reasoning (Johnson, 1999). It is believed that the challenge of the decade was that the teachers' work and their mental lives must be repositioned in the study of teaching. In the next decade, the 1900s to 2000s, there is no fundamental new paradigm. It is the era of consolidation and deepening. 'The notion of teachers' mental lives was firmly established as a matter of public policy' (Freeman, 2002: 8). Hence, the research about teachers' knowledge is still dominant in the field of Teaching Education. Borg (2006) states that:

As we moved into a new millennium,
interest in the study of teacher
cognition showed no sign of
abating...As we moved past the
midpoint of the current decade, the
contents pages of key research
journals in education, and
particularly in teacher education,
highlight continuing interest in the
study of teacher cognition...the March 2020, Volume 3, Issue 1 
predominant focus today is on understanding teacher knowledge (used as an umbrella term for a range of psychological constructs) its growth and use. Teacher cognition research today is aligned particularly closely with work in teacher education; a key role for such research it to support teacher learning at both pre service and in-service level (2006: 32-35).

Addressing to teaching practice or practicum, there has been the same shift to focus. Therefore, in the following sections, the discussion of topics regarding how the student teachers perceived the best practices during the practicum will be categorized into student teacher learning, student teachers' cooperation with cooperating teachers, and university-school partnership in the practicum.

\section{DISCUSSION}

\subsection{Student Teaching Learning}

Research on student-teacher learning during practicum covers such areas as student teachers' main concerns, student teachers' experiences, what and how student teachers learn and how specific innovations by particular universities contribute to teacher learning. The student teachers' concern here is not only about the improvement of their pedagogical and content knowledge after the practicum, but also about the change of professional identity they feel after experiencing teaching in the practicum. Teacher identity is generally defined as teachers' professional self' and how teachers feel or perceive themselves professionally as teachers ( He \& Lin, 2013: 206).

Being perceived as a particularly stressful and demanding period, which involves considerable amounts of distress, practicum, based on some studies, has given positive effects on the student teachers' efficacy or competence, skills, knowledge, teaching performance, and interactions (Atay, 2007; Caires, Almeida, \& Viera, 2012). The awareness of managing, instruction, engaging the students becomes one of the factors that had encouraged the student teachers to work hard to improve their self-efficacy (Atay, 2007). The growing of knowledge and skill of teaching seems to provide an effect on the student teachers' confidence, flexibility, spontaneity, and interactions with the pupils (Goh, Wong, Choy, \& Tan, 2009; He \& Lin, 2013; Choy, Wong, Goh, Low, 2014). For some student teachers, their experiences during the practicum have changed their perceptions about the teaching of English to a certain group of learners and in a certain context. The sense of identity as teachers (or prospective teachers) appears after the process of interactions with students. Identity also means "our understanding of who we are and who we think other people do" (Trent, 2013). A student teacher, Lynn, took part very enthusiastically in various teaching practice activities. She was eager to undertake the practicum to initiate transformations in both her students and herself. How she perceives or 
believes the essence of teaching also changed. For example, she believes that 'teaching knowledge is not the most important objective but rather educating people, and the teacher has his/her own preference in teaching lessons according to her/his own style (He \& Lin, 2013). Regarding the one's preference in using a certain technique, another research also reports the same case, that the student teachers want to be more independent and flexible in selecting the teaching content and the method of teaching as in their own way (Beck \& Kosnik, 2002).

Reports also show several problems or difficulties the student teachers still face during the practicum session. Research reveals that some student teachers still struggled to be emotionally involved to relate themselves with their students. One of the causes is 'the lack of leadership competence'. Leadership is defined as 'inter-related domains of commitment and knowledge which encompasses moral and responsibility and commitments to learn continuously. Moral responsibilities are related to how student teachers understand their roles as a teacher not just in the class, but also their roles within the social and political context of a school and the wider society. The researcher reported that the student teachers' lack of leadership qualities prompted other problems for them in schools that they were less likely to be respected as real teachers by students in classrooms (Kuswandono, 2017). These aspects, according to instructional approach to learners. Based on this finding, the researcher suggested the future researchers to critically examine how emotional and interpersonal involvement can induce stronger the student teachers' identity, including their leadership ability in the school-based practicum. One of the reasons, according to the CTs was the time or duration allowed for teaching practicum in the school which was too short. It is likely that, based on the teacher's opinion, this made the student teachers difficult in being engaged with the school students and staff. It also has become the concern of another researcher, Mutlu (2014). Two recommended areas to get more exploration are to examine the relationship between the duration or allocated time for practicum and the student teachers' leadership skills and the effect on the instructional performance in the classroom. The other need for study is to seek alternatives for the student teachers to gain optimal practicum with the allotted time given or spent in schools.

In addition, the inadequacy in English language competence is the other problem the student teachers still face in the teaching. It has impeded the interactions with the pupils in the classrooms. It may cause the student teachers to avoid using the target language and languageintensive teaching practice in their classroom, feel anxious due to the concern over making errors, and appeal foolish in the eyes of their peers, conversational partners, and 
students (Gan, 2013; Danyal Oztas Tum, 2015). Then, it will become one of the concerns of the preparation program on campus to prepare their subject matter knowledge competence before they are sent to the schools for practicum.

\subsection{Cooperating Teachers}

Mentoring has become a crucial aspect in pre-service teacher education. Classroom teachers who do the mentoring to student teachers are called mentors or in other terms, such as mentor teachers, cooperating teachers, school-based teacher educators, school associates, practicum supervisors (Ambrosetti, 2014). In this article, the term 'cooperating teachers' will be used.

Mentoring is a holistic process, including three main components; relationship, developmental needs, and contextual elements (Ambrosetti \& John, 2010). She adds the relationship component focuses on the relationship between the cooperating teachers or mentors and the student teachers or mentees. The developmental aspect refers to how mentors and mentees develop personally and professionally based on certain goals, and the contextual component focuses on the cultural and situational features of the placement setting. Ambrosetti also perceives that 'Mentoring concerns the development of the relationship between the mentor and the mentee. So in mentoring the relationship becomes central to the interactions that occur' (2014).
Cooperating teachers play important roles in preparing a new generation of teachers. In playing their roles during the mentoring of the mentees or student teachers effectively, cooperating teachers have to be well informed with the student teachers' needs. Understanding their student teachers' needs also will help them to build a good relationship (Leshem, 2012). It has been said that teaching practice or practicum is perceived as a particularly stressful and demanding period. The student teachers have to deal with not only performing the subject matter, knowledge of the subject taught, skills in teaching, interacting with pupils but also facing new situations or context of learning. Problems potentially occur during dealing with these conditions. Student teachers need help from both cooperating teachers and their supervisors in the university. Regarding the teachers' responsibility for mentoring, the roles of cooperating teachers and their interactions with the student teachers become one of the main concerns of many researchers.

Regarding the knowledge and skills expected to achieve or to master by the student teachers, there were some studies aiming at exploring the areas of help the student teachers need to get or to learn from their mentors or cooperating teachers. One of the studies was done from 2002 to 2003 by Atputhasamy from the National Institute of Education, Singapore (2005). The areas of desired help were to explore are: (1) the curriculum of the subject, (2) classroom 
management, (3) evaluation and feedback, and (4) the information to function well in the school (e.g. the school system and culture, balance between personal life and teaching life). The findings of the study reveal that there are eight subareas considered important by most of the students, i.e. suggesting ways to improve teaching skills, providing constructive criticism and fair evaluation, providing guidance as to how effectively teach the content of the subject, teaching techniques to handle difficult students in the class, providing opportunity to observe experienced teachers teaching, showing effective ways of managing different types of classrooms, sharing teaching materials/resources that are related to the teaching of the subjects, and providing a profile of the classes to teach. From those areas, there were only three areas more than 50 percent of the student teachers perceived having received sufficient help: suggesting ways to improve teaching skills, providing constructive criticism and fair evaluation on their teaching, and giving an opportunity to try out teaching approaches. However, based on this investigation, it also reveals that the level of help provided in these areas was below the level of the student teachers' expectations. Based on the data given by the student teachers to the open-ended questionnaire, it shows that the cooperating teachers, who should play an effective role in the teacher education program, seemingly need to acquire the necessary knowledge and skills and a positive attitude towards their roles as partners in teacher education. Another research also revealed some similar findings related to the cooperating teacher's help in the implementation of curriculum, teaching strategies, classroom management, and professional desicions that as the student teachers navigate their way through the practicum, the cooperating teacher is likely to have a strong influence on the student teachers' decisions regarding the implementation of the curriculum, teaching strategies, classroom management, dan professional decisions (Roofe \& Cook, 2017).

Another study conducted by Harvey (2012) also showed the student teachers' perceptions and experiences during the practicum. Although it was more focused on their experiences regarding teaching practice, it was indirectly suggesting the roles of cooperating teachers to provide supervision particularly in the period of transitions to give technical and emotional support. Finding emotional support also becomes one of the strategies the student teachers coped with practicum stress (Harvey, 2014). Quoted from an article written by Beck \& Kosnik (2002) it says that:

\footnotetext{
"In the second practicum I had instant rapport with my associate teacher; she made me feel very comfortable. One of the first things she said to me was, " I understand how important this report is, and I don't want you to worry because I'm not going to give you a bad report. "She also said, "You know, you're
} 
here to learn, you're here to make mistakes; we all make mistakes when we're starting. "So she gave me freedom to experiment that I didn't have during the first practicum.' (Liz, student teacher)

Looking into the above quotation, it is clearly understood that student teachers want the cooperating teachers to give emotional support, such as being friendly and supportive, being respected and treated as a peer, being flexible in selecting what to teach and how to teach.

Cooperating teachers' attitudes while interacting with the student teachers also becomes another concern in the practicum. CTs' attitude is the focus of a study in teacher education (Mutlu, 2014). Investigating the attitudes of the CTs in welcoming and interacting with student teachers. One of the respondents commented besides having a lack of English proficiency, the $\mathrm{CP}$ also showed rude behavior.

The teachers in the cooperating school are very rude to us. For example, the first time I and my friends went to our practicum school, the teachers said that it was forbidden for us to sit in the teachers' room and there was a small room upstairs allocated for us. They did not let us enter that room, they always said that we were not teachers; we were only trainees so they would call us when they needed us. They even sometimes make us do their own things, we worked for an extra two hours to prepare a worksheet for them to use in their classes.
I really feel that they are disturbed by our presence in their classes and even in school. Especially female teachers do not want to answer our questions and usually give short answers just to get rid of us. I think teachers do not want to accept us as their colleagues as they still see us as students. They do not allow us to use their equipment and I am really curious about the reason behind this. For example, one of the teachers said to me that I could not use the photocopy machine to copy my activities and I needed to copy them somewhere outside.

So based on this result, it is recommended to have a unit in the practicum department in the institute of teacher education that the main goal is to help the CTs to construct their knowledge and understanding of teaching and develop skills to mentor and guide prospective teachers. This has led to some opportunities to conduct further research on, for example, investigating the $\mathrm{CTs}^{\prime}$ perceptions of their roles in the partnership during the practicum and exploring the ideal and clear communication between university and schools, identifying and finding the selection criteria of the teacher expertise.

Again, cooperating teachers take an essential element in teaching practicum. They have a responsibility to produce student teachers who are professional as teachers. To fulfill these roles and responsibilities, like teachers, they need to have good skills, knowledge, competence, and confidence. An effective cooperating 
teacher models examples of good practices for students teachers to evaluate and emulate (Glenn, 2006). These abilities are not given naturally. Richards and Crookes also noted that the role of the cooperating teachers has been poorly defined and classroom teachers are usually not well prepared for the task of supervising (1988: 23). So knowledge, skills, competence, and confidence of a cooperating teacher, particularly when she/he supervises her/his student teachers must be learned. Therefore, before supervising cooperating teachers, a training program is important (Farrell, 2001; Ambrosetti, 2014). Research reports the role of professional development in the four weekly-after school preparation program for cooperating teachers (Ambrosetti, 2014). This program basically aimed to develop the cooperating teachers' knowledge about nature and the process of mentoring. The investigation reveals the cooperating teachers' opinions about the mentoring process. Many of the teachers (respondents) did not typically consider mentoring a complex activity. Some of the participants identified that the role of a cooperating teacher essentially is not only developing essential teaching knowledge and skills but also providing emotional support to the mentees or student teachers. It can be concluded from the research that the classroom teachers who will become mentors need some preparation.

\subsection{School-University Collaboration in Practicum}

School-university partnership has been widely practiced in many education institutions since one or two decades ago. At the end of the 1980s the increasing dissatisfaction with 'teaching practice' culminated in a UNESCO report. Teacher preparation was considered insufficient because of the lack of a link between the theories taught at the institution and the school's situations and needs. This led pre-service teacher institutions almost all over Europe, the USA, and Australia made some changes in their teacher education policies; one of them was the encouragement to develop a strong school-partnership (Bezzina, Lorist, and van Velzen, 2006) Teaching practicum at schools seems quite a popular form of the partnership that the main purposes are to bridge and to prepare prospective teachers to be ready and understand the nature of teaching profession, norms of schooling, and the work of schools (Suratno, 2008; Smith, 2006; Halasz, 2016), and provides a 'reality check' for teacher educators on the relevance of what they teach in the second language education context (Graves, 2009). A partnership through a practicum at schools can be also said as the form of shared understanding that teacher education is no longer a university problem but a joint schooling and university responsibility (Allen \& Peach, 2007).

Reports revealed that those involved in the university-school 
partnership during the practicum wanted clear information about their roles in the practicum and sustained and open communication between stakeholders in the partnership, and the anticipation of possible conflicts among them (Allen, Ambrosetti, \& Turner, 2013; Uusimaki, 2013; Allan, 2011). Some of them said that they did not really understand their responsibility in the practicum. Another aspect to be considered in this research is how to select who will participate in the partnership and the school where the student teachers will be placed for the practicum. From the student teachers' perspective on the partnership between university and school, In a different research, a group of student teachers suggested that the educational institutions from where they were sent need to provide clarity on the expected roles of the cooperating teachers as they supervise them during the practicum. This gave an impact on the cooperating teachers' ability to provide adequate supervision (Roofe \& Cook, 2017). Moreover, to improve the practicum experience, some student teachers suggested that in the partnership during the practicum, the support from the university and the connectedness between learning on campus and in the field need to be concerned too (Orlando-Barack \& Hasin, 2010).

\section{CONCLUSION}

The review of research literature on student teachers and cooperating teachers cognitions, and collaboration between universities and schools during the practicum reveals some important points for researchers, educators, and policymakers about the effects of practicum for the development of student teachers' teaching knowledge and skills and their affective factors considered in teaching pupils, the roles of cooperating teachers during the practicum period, and the contribution of university-school partnership for the student teaches' success, particularly in the practicum.

Based on the studies reviewed above, it can be concluded that teaching practice or practicum has brought some changes to the student teachers' performance in teaching, relationships with the pupils, cooperating teachers, and university supervisors during their interactions in the program. However, information about the effectiveness of the practicum practices on the same aspects discussed above still needs to be explored with some additional focus, such as the process of student teachers' placement in the selected teaching practice schools, time allotted for practicum, and practicum assessment.

\section{REFERENCES}

Allen, J.M., Ambrosetti, A., and Turner, D. 2013. How school and university supervising staff perceive the pre-service teacher education practicum: a comparative study. Australian Journal of Teacher Education. 38(4), 108-125.

Allen, J.M. 2010. Stakeholders' perspectives of the nature and 
role of assessment during practicum. Teaching and Teacher Education. 27: 742-750.

Allen, J.M and Peach, D. 2007. Exploring connections between the in-field and oncampus components of a preservice teacher education program: a student perspective. Asia-Pasific Journal of Cooperative Education. 8(1), 23-36.

Ambrosetti, A. and John, D. 2010. The interconnectedness of the roles of mentors and mentees in pre-service teacher education mentoring relationship. Australian Journal of Teacher Education. 35(6), 42-55.

Ambrosetti, A. 2014. Are you ready to be a mentor?: preparing teachers for mentoring preservice teachers. Australian Journal of Teacher Education. 39(6).

Atputhasamy, L. 2005. Cooperating teachers as school based teacher educators: Student Teachers' Expectation. Australian Journal of Teacher Education. 30(2).

Atay, D. 2007. Beginning teacher efficacy and the practicum in an EFL context. Teacher Development. 11 (2), 203-219.

Beck, C. and Kosnik, C. 2002. Components of a good practicum placement studentteacher perception. Teacher Education Quarterly. 29(2), 8198.
Bezzina, C., Lorist, P., and van Velzen, C. 2006. Partnership between schools and teacher education institutes. A paper presented in the 31st Annual Conference of Association of Teacher Education in Europe.

Borg, S. 2006. Teacher cognition and language education: research and practice. London: Continuum.

Borg, 2003. Teacher cognition in language teaching: a review of what language teachers think, know, believe, and do. Language Teach. 36: 81-109.

Caires, S., Almeida, L, and Viera, D. Becoming a teacher: student teachers' experiences and perceptions about teaching practice. European Journal of Education. 35(2), 163-178.

Choy, D., Wong, A.F.L., Goh, K.C., and Low, E.L. 2014. Practicum experience: pre-service teachers' self-perception of their professional growth. Innovation in Education and Teaching International. 51(5), 472-482.

Danyal Oztas Tum. 2015. Foreign language anxiety's forgotten study: the case of the anxious preservice teacher. TESOL Quarterly. 49(4), 627-658.

Farrell, T. 2001. English language teacher socialisation during the practicum. Prospect. 16(1), 49-62.

Freeman,D. 2002. The hidden side of the work: teacher knowledge and learning to teach. A perspective from north American educational 
research on teacher education in English language teaching. Language Teaching. 35(1), 1-13.

Gan, Z. 2013. Learning to teach English language in the practicum: what challenges do non-native ESL student teachers face?. Australian Journal of Teacher Education. 38(3), 92-108.

Gebhard, J.G. 2009. The practicum. In Burns, A. and Richards, J.C. The Cambridge guide to second language teacher education. Cambridge: Cambridge University Press.

Glenn, W.J. 2006. Model versus mentor: defining the necessary qualities of the effective cooperating teacher. Teacher Education Quarterly. 33(1), 85-95.

Goh, K.C., Wong, A.F.L., Choy, D., and Tan, J.P.I. 2009. Confidence levels after practicum experiences of student teachers in Singapore: an exploratory study. KEDI Journal of Educational Policy. 6(2), 121-140.

Graves, K. 2009. The curriculum of second language teacher education. In Burns, A. and Richards, J.C. The Cambridge guide to second language teacher education. Cambridge: Cambridge University Press.

Halasz, G. 2016. School-university Partnership for Effective Teacher Learning. http://halaszg.ofi.hu/downlo ad/May 13 Issues paper.pdf
He, P., and Lin, A.M.Y. 2013. Tension in school-university partnership and EFL preservice teacher identity formation: a case in mainland China. The Language Learning Journal. 41(2), 205-218.

Johnson, K.E. 1999. Understanding language teaching: reasoning in action. Boston: Heinle and Heinle.

Kuswandono, P. 2017. Mentor teachers' voices on pre-service English teachers' professional learning. Indonesian Journal of Applied Linguistics. 6(2), 213221.

Leshem, S. 2012. The many faces of mentor-mentee relationships in a pre-service teacher education programme. Creative Education. 3(4), 413421.

Mutlu, G. 2014. Challenges in Practicum: Pre-Service and Cooperating Teachers' Voices. Journal of Education and Practice. 5(36).

Ong'ondo, C. and Jwan, J.O. 2009. Research on student teacher learning: collaboration and supervision during the practicum: a literature review. Educational Research and Review. 4(11), 515-524.

Richards, J.C. and Crookes, G. 1988. The practicum in TESOL. TESOL Quarterly. 22(1), 9-27.

Roofe, C.G. and Cook, L.D. 2017. Cooperating teachers, school placement and the implementation for quality. 
Australian Journal of Teacher Education. 42(6), 35-50.

Smith, K. 2016. Partnership in teacher education- going beyond the rhetoric, with reference to the Norwegian context. CEPS Journal 6 (3), 17-34.

Suratno, T. 2008. School-University Partnership in Indonesia: A Case Study. Presented in International Conference on Lesson Study, Faculty of Mathematics and Science Education Indonesia
University of Education July 31 - August 01, 2008

Trent, J. 2013. From learner to teacher: practice, language, and identity in a teaching practicum. Asia-Pasific Journal of Teacher Education. 41(4), 426440.

Uusimaki. L. 2013. Empowering preservice teacher supervisors' perspectives: a relationalcultural approach toward mentoring. Australian Journal of Teacher Education. 38(7) 